\title{
HUBUNGAN FAKTOR SOSIODEMOGRAFI DAN LINGKUNGAN DENGAN DIARE PADA ANAK BALITA DI DAERAH ALIRAN SUNGAI TONDANO
}

\author{
${ }^{1}$ Marlina G. O. Soentpiet \\ ${ }^{2}$ Jeanette I. Ch. Manoppo \\ ${ }^{3}$ Rocky Wilar
}

\author{
${ }^{1}$ Kandidat Skripsi Fakultas Kedokteran Universitas Sam Ratulangi Manado \\ ${ }^{2}$ Bagian Ilmu Kesehatan Anak Fakultas Kedokteran Universitas Sam Ratulangi \\ Email: nsoentpiet@gmail.com
}

\begin{abstract}
Diarrhea is still a health problem in the world which can be seen from the high rates of morbidity and mortality due to diarrhea in children worldwide. In patients with diarrhea, nutrients needed by the body are excreted along with the occurence of body dehydration. Therefore, when a child under five years has diarrhea oftenly, then his/her growth can not be optimal. This was an analytical observational study with a cross sectional approach, conducted in Tondano Watershed during November to December 2014. Subjects were 70 children under five years old. Data were collected by using questionnaires and then were analyzed with the chi-square test. The results showed that there was no correlation between sociodemographic factors (education, occupation, and ages of the mothers), sources of drinking water, and house floors with the occurence of diarhhea $(P>0.05)$. However, there was a correlation between excreta disposal sites and the occurence of diarrhea $(P=0.003)$. Conclusion: There was a correlation between excreta disposal site with diarrhea in Tondano watershed and there was no correlation between the level of education, parents' occupation, maternal age, source of drinking water, and the type of floor house and diarrhea.
\end{abstract}

Keywords: diarrhea, children under five years, sociodemographic factors, environmental factors

\begin{abstract}
Abstrak: Diare masih menjadi masalah kesehatan di dunia. Masalah tersebut terlihat dari tingginya angka morbiditas dan mortalitas akibat diare pada anak di seluruh dunia. Pada penderita diare, zat-zat makanan yang masih diperlukan tubuh terbuang bersamaan dengan dehidrasi. Oleh karena itu, bila anak balita sering mengalami diare, maka pertumbuhannya tidak akan berlangsung secara optimal. Penelitian ini menggunakan metode observasional analitik dengan pendekatan potong lintang, dilakukan di Daerah Aliran Sungai Tondano selama bulan November-Desember 2014. Subyek penelitian sebanyak 70 orang anak. Pengumpulan data menggunakan kuesioner, dan data dianalisis dengan chi-square. Hasil penelitian menunjukkan tidak terdapat hubungan antara faktor sosiodemografi yang meliputi tingkat pendidikan ibu $(\mathrm{p}=0,146)$, jenis pekerjaan ibu $(\mathrm{p}=0,089)$, dan umur ibu $(\mathrm{p}=0,053)$. Untuk faktor lingkungan yang meliputi sumber air minum $(\mathrm{p}=0,349)$ tidak berhubungan, jenis tempat pembuangan tinja $(p=0,003)$ berhubungan, dan jenis lantai rumah $(p=0,264)$ tidak berhubungan. Simpulan: Terdapat hubungan antara tempat pembuangan tinja dengan diare di Daerah Aliran Sungai Tondano dan tidak terdapat hubungan antara tingkat pendidikan, pekerjaan orang tua, usia ibu, sumber air minum dan jenis lantai rumah dengan diare.
\end{abstract}

Kata kunci: diare, anak balita, faktor sosiodemografi, faktor lingkungan 
Diare sampai saat ini masih menjadi masalah kesehatan di dunia, masalahmasalah tersebut terlihat dari tingginya angka morbiditas dan mortalitas akibat diare pada anak di seluruh dunia. Sebagian besar kasus diare adalah anak-anak di bawah umur 5 tahun. ${ }^{1}$

Setiap tahun diperkirakan 2,5 miliar kejadian diare pada anak balita, dan hampir tidak ada perubahan dalam dua dekade terakhir. Diare pada balita tersebut lebih dari separohnya terjadi di Afrika dan Asia Selatan dan dapat mengakibatkan kematian atau keadaan berat lainnya. Insidens diare bervariasi menurut musim dan umur. Anakanak adalah kelompok usia rentan terhadap diare, insiden diare teringgi pada keompok anak usia dibawah dua tahun, dan menurun dengan bertambahnya usia anak. ${ }^{2}$ Pada penderita diare, zat-zat makanan yang masih diperlukan tubuh terbuang bersamaan dengan terjadinya dehidrasi. Oleh karena itu, apabila anak balita sering mengalami diare, maka pertumbuhannya tidak dapat berlangsung secara optimal. ${ }^{3}$

Banyak faktor risiko yang diduga menyebabkan terjadinya penyakit diare pada bayi dan balita di Indonesia. Salah satu faktor risiko yang sering diteliti adalah faktor lingkungan yang meliputi sarana air bersih (SAB), sanitasi, jamban, saluran pembuangan air limbah (SPAL), kualitas bakterologis air, dan kondisi rumah. Data terakhir menunjukkan bahwa kualitas air minum yang buruk menyebabkan 300 kasus diare per 1000 penduduk. Sanitasi yang buruk dituding sebagai penyebab banyaknya kontaminasi bakteri E.coli dalam air bersih yang dikonsumsi masyarakat. Bakteri E.coli mengindikasikan adanya pencemaran tinja manusia. Penyediaan air bersih dan pembuangan tinja akan berinteraksi bersama dengan perilaku manusia, dan jika lingkungan tidak sehat karena tercemar kuman diare disertai perilaku manusia yang tidak sehat maka penularan diare dapat terjadi. Faktor sosiodemografi juga berpengaruh dalam terjadinya diare pada anak balita yaitu pendidikan orang tua, pekerjaan dan umur anak balita juga merupakan faktor yang dominan dalam terjadinya diare. ${ }^{4}$

Di Provinsi Sulawesi Utara, penyakit diare merupakan penyakit yang potensi- al menimbulkan Kejadian Luar Biasa (KLB). Tahun 2009 jumlah kasus diare sebanyak 28.782. Tahun 2010 jumlah kasus diare sebanyak 25.442 kasus, tahun 2011 jumlah kasus diare sebanyak 20.234 kasus, sedangkan tahun 2012 jumlah kasus Diare 28.072 kasus. ${ }^{5}$ Danau Tondano adalah danau yang terletak di Sulawesi Utara tepatnya di wilayah kabupaten Minahasa. Danau Tondano hanya mempunyai satu aliran keluar danau yang menuju sungai Tondano dan bermuara di Teluk Manado. Kegiatan peternakan, dan limbah rumah tangga antar lain, kotoran hewan dan kotoran manusia yang di lakukan oleh masyarakat setempat memberikan peningkatan konsentrasi bahan organik dan menurunkan kulaitas air. ${ }^{6}$

Berdasarkan penelitian studi populasi bakteri yang dilakukan di Daerah Aliran Sungai Tondano peneliti menemukan adanya bakteri E. coli di sungai Tondano yang bisa menyebabkan terjadinya diare. ${ }^{7}$

Berdasarkan profil Dinas Kesehatan Provinsi Sulawesi Utara tahun 2013, diare tertinggi di Sulawesi Utara pada tahun 2012 adalah di Kabupaten Minahasa yaitu sebanyak 2.834 kasus. Di bagian hulu Daerah Aliran Sungai Tondano, Remboken adalah daerah yang mempunyai kasus diare lebih tinggi dibandingkan daerah-daerah di hulu DAS Tondano, sedangkan di bagian hilir daerah Ternate Tanjung merupakan daerah yang mempunyai kasus diare lebih tinggi dibandingkan daerah yang di hilir DAS Tondano lainnya. ${ }^{8}$

Berdasarkan uraian di atas maka peneliti tertarik untuk melakukan penelitian mengenai Hubungan Faktor Sosiodemograf dan Lingkungan dengan Diare pada Anak Balita di Daerah Aliran Sungai Tondano.

\section{METODE PENELITIAN}

Penelitian ini menggunakan metode observasional analitik dengan pendekatan potong lintang dan dilakukan di bagian hulu Remboken Tondano, Kabupaten 
Minahasa dan di hilir Kelurahan Ternate Tanjung, Singkil Kota Manado.

Populasi penelitian ialah seluruh anak balita di Daerah Aliran Sungai Tondano di bagian hulu Remboken Tondano, Kabupaten Minahasa dan di hilir Kelurahan Ternate Tanjung, Singkil Kota Manado. Sampel dipilih berdasarkan kriteria inklusi yang sudah ditetapkan yaitu: Bertempat tinggal di hulu dan hilir, mempunyai anak balita, dan bersedia menjadi subjek penelitian, dan dihitung dengan rumus sehingga di dapatkan jumlah sampel sebanyak 70 sampel.

Variabel penelitian terdiri atas variabel bebas dan variabel terikat. Variabel bebas ialah faktor sosiodemografi yang meliputi pendidikan ibu, pekerjaan ibu, umur ibu, dan faktor lingkungan, meliputi sumber air minum, tempat pembuangan tinja dan jenis lantai rumah, sedangkan variabel terikat ialah diare pada balita.

Pengumpulan data dilakukan dengan menggunakan instrumen penelitian seperti kuesioner, alat tulis menulis, dan komputer. Kuesioner dibagikan kepada setiap ibu yang mempunyai anak balita di Remboken dan Ternate Tanjung selama bulan November-Desember 2014.

\section{HASIL PENELITIAN}

Tabel 1. Karakteristik sampel penelitian berdasarkan umur anak balita

\begin{tabular}{lcccc}
\hline \multicolumn{1}{c}{ Umur } & \multicolumn{2}{c}{ Diare } & \multicolumn{2}{c}{ Tidak Diare } \\
\hline & $(\mathrm{n})$ & $(\%)$ & $(\mathrm{n})$ & $(\%)$ \\
\hline $0-6$ bulan & 4 & 8,3 & 1 & 4,5 \\
$6-12$ bulan & 5 & 10,4 & 1 & 4,5 \\
$1-3$ tahun & 17 & 35,4 & 8 & 36,4 \\
$3-5$ tahun & 22 & 45,8 & 12 & 54,5 \\
\hline Jumlah & 48 & 100 & 22 & 100 \\
\hline
\end{tabular}

Tabel 2. Karakteristik sampel penelitian berdasarkan jenis kelamin anak balita

\begin{tabular}{lccrc}
\hline Jenis Kelamin & \multicolumn{2}{c}{ Diare } & \multicolumn{2}{c}{ Tidak Diare } \\
\hline & $(\mathrm{n})$ & $(\%)$ & $(\mathrm{n})$ & $(\%)$ \\
\hline Laki-laki & 30 & 62,5 & 8 & 36,4 \\
Perempuan & 18 & 37,5 & 14 & 63,6 \\
Jumlah & 48 & 100 & 22 & 100 \\
\hline
\end{tabular}

Tabel 3. Analisis Hubungan antara Umur Ibu dengan Diare

\begin{tabular}{lccc}
\hline Distribusi & $\mathrm{n}$ & $\%$ & $\mathrm{Uji} \mathrm{X}^{2}(\mathrm{p})$ \\
\hline Umur Ibu & & & \\
Resiko Tinggi & 10 & 20,8 & \\
Rendah & 38 & 79,2 & $(0,053)$ \\
Jumlah & 48 & 100 & \\
\hline
\end{tabular}

Tabel 4. Analisis Hubungan antara Pendidikan Ibu dengan Diare

\begin{tabular}{lccc}
\hline Pendidikan & $\mathrm{n}$ & $\%$ & $\mathrm{Uji} \mathrm{X}^{2}(\mathrm{p})$ \\
\hline Rendah & 8 & 16,7 & \\
Sedang & 38 & 79,2 & $(0,146)$ \\
Tinggi & 2 & 4,1 & \\
Jumlah & 48 & 100 & \\
\hline
\end{tabular}


Tabel 5. Analisis Hubungan antara Pekerjaan Ibu dengan Diare

\begin{tabular}{lccc}
\hline Pekerjaan & $\mathrm{n}$ & $\%$ & $\mathrm{Uji} \mathrm{X}^{2}(\mathrm{p})$ \\
\hline Tidak Bekerja & 36 & 75,0 & \\
Bekerja & 12 & 25,0 & $(0,089)$ \\
Jumlah & 48 & 100 & \\
\hline
\end{tabular}

Tabel 6. Analisis Hubungan Antara Sumber Air dengan Diare

\begin{tabular}{lccc}
\hline Distribusi & $\mathrm{n}$ & $\%$ & $\mathrm{Uji} \mathrm{X}^{2}(\mathrm{p})$ \\
\hline Sumber Air & & & \\
Tidak Terlindung & 35 & 72,9 & \\
Terlindung & 13 & 27,1 & $(0,349)$ \\
Jumlah & 48 & 100 & \\
\hline
\end{tabular}

Tabel 7. Analisis Hubungan antara Tempat Pembuangan Tinja dengan Diare

\begin{tabular}{llll}
\hline Distribusi & $\mathrm{n}$ & $\%$ & $\mathrm{Uji} \mathrm{X}^{2}(\mathrm{p})$ \\
\hline Tempat Pembuangan Tinja & & & \\
Tidak Sehat & 30 & 62,5 & \\
Sehat & 18 & 37,5 & $(0,003)$ \\
Jumlah & 48 & 100 & \\
\hline
\end{tabular}

Tabel 8. Analisis Hubungan antara Jenis Lantai dengan Diare

\begin{tabular}{lccc}
\hline Distribusi & $\mathrm{n}$ & $\%$ & $\mathrm{Uji} \mathrm{X}^{2}(\mathrm{p})$ \\
\hline Jenis Lantai & 18 & 37,5 & \\
$\quad$ Kedap Air & 30 & 62,5 & \\
$\quad \begin{array}{l}\text { Tidak kedap air } \\
\text { Jumlah }\end{array}$ & 48 & 100 & $(0,264)$ \\
\hline
\end{tabular}

\section{BAHASAN}

Pada penelitian ini populasi dilakukan pada anak-anak balita dikarenakan sebagian besar kasus diare ialah anak-anak di bawah 5 tahun. Tabel 1 menunjukkan yang mendapat diare terbanyak ialah umur 3-5 tahun yaitu 22 anak (45,8\%). Tabel 2 menunjukkan jenis kelamin terbanyak pada anak laki-laki yaitu 30 anak (62,5\%).

Berdasarkan Tabel 3, umur ibu pada kelompok risiko rendah (20-35 tahun) yang paling banyak mempunyai anak balita dengan diare yaitu sebanyak 38 (79,2\%) dari 70 sampel. Hasil perbandingan tersebut di uji dengan menggunakan chi square dengan hasil $\mathrm{p}=0,053(\mathrm{p}=>0,05)$ yang menunjukkan tidak terdapat hubungan antara umur ibu dengan diare pada anak balita. Penelitian ini sejalan dengan penelitian yang di lakukan oleh Irianti yang menunjukkan umur ibu tidak berhubungan dengan kejadian diare. ${ }^{9}$ Sampel terbanyak pada umur 20-35 tahun karena umur tersebut usia subur seorang ibu.

Berdasarkan Tabel 4 diketahui pendidikan ibu pada kelompok sedang (SMP dan SMA) yang paling banyak mempunyai anak balita yang menderita diare sebanyak 38 (79,2\%) dari 70 sampel. Hasil perbandingan tersebut di uji dengan menggunakan chi square dengan hasil $\mathrm{p}=$ 0,146 atau $\mathrm{p}=>0,05$ yang menunjukkan tidak terdapat hubungan antara pendidikan ibu dengan diare pada anak balita. Penelitian ini serupa dengan hasil penelitian yang dilakukan oleh Sander bahwa tidak ada hubungan antara pendidikan ibu dengan diare pada anak balita. $^{10}$

Berdasarkan Tabel 5 diketahui pada 
kelompok ibu yang tidak bekerja yang paling banyak menderita diare sebanyak 36 anak (75,0\%) dari 70 sampel. Hasil perbandingan tersebut diuji dengan chi square dengan hasil $\mathrm{p}=0,089(\mathrm{p}=>0,05)$, yang menunjukkan tidak ada hubungan antara pekerjaan ibu dengan diare pada anak balita. Penelitian ini sejalan dengan penelitian yang dilakukan oleh Wijaya yang menunjukkan faktor ibu bekerja atau tidak bekerja tidak berhubungan dengan kejadian diare pada anak balita. ${ }^{11}$

Berdasarkan Tabel 6 diketahui pada penggunaan sumber air yang tidak terlindung yang paling banyak menderita diare yaitu sebanyak 35 (72,9\%). Hasil perbandingan tersebut diuji dengan menggunakan chi square dengan hasil $\mathrm{p}=$ $0,349(\mathrm{p}=>0,05)$ yang menunjukaan tidak terdapat hubungan antara sumber air dengan diare pada anak balita. Hasil penelitian ini bertentangan dengan penelitian yang dilakukan oleh Zubir $^{12}$ bahwa sumber air berhubungan dengan kejadian diare. Penduduk Remboken dan Terante Tanjung paling banyak menggunakan sumber air yang tidak terlindung yaitu sumur namun menurut wawancara dengan responden air sumur yang di konsumsi berasal dari satu sumur dan sumur tersebut di bawah pengawasan puskesmas setempat sehingga sumber air yang digunakan tidak berhubungan dengan diare.

Dari Tabel 7 berdasarkan tempat pembuangan tinja diketahui sebanyak 30 $(62,5 \%)$ dari 70 sampel yang yang menggunakan jamban tidak sehat anak balitanya yang paling banyak menderita diare. Hasil perbandingan tersebut diuji dengan menggunakan chi square dengan hasil $p=0,003(p=<0,05)$. Hasil penelitian ini sejalan dengan penelitian yang dilakukan oleh Zubir ${ }^{12}$ bahwa tempat pembuangan tinja berpengaruh dalam kejadian diare. Penelitian ini juga mendukung penelitian yang dilakukan oleh Wibowo $^{13}$ yaitu tempat pembuangan tinja yang tidak memenuhi syarat akan meningkatkan resiko terjadinya diare. Pada penelitian ini responden masih ada yag membuang kotoran langsung di sungai ada juga jamban leher angsa tapi tidak mempunyai septic tank dan kotoran langsung ke sungai dan lubang galian sehingga banyak jamban yang kotor.

Dari Tabel 8 berdasarkan jenis lantai diketahui sebanyak 30 (62,5\%) dari 70 sampel, menggunakan lantai tidak kedap air dan anak balitanya yang paling banyak menderita diare. Hasil perbandingan tersebut diuji menggunakan chi square dengan hasil $p=0,264(p=>0,05)$, yang berarti tidak terdapat hubungan antara jenis lantai dengan diare pada anak balita. Hal ini bertentangan denga penelitian yang dilakukan oleh Anjar yaitu jenis lantai memengaruhi kejadian diare pada anak balita.

Pada penelitian ini lantai para responden terbanyak yaitu lantai tidak kedap air dalam hal ini lantai papan/bambu dan tanah, namun berdasarkan penelitian lantai para responden dalam keadaan bersih. Menurut responden lantai selalu bersih dikarenakan anak-anak balita sering bermain di lantai. Untuk lantai tanah kebanyakan dalam keadaan disiram dan dipadatkan.

\section{SIMPULAN}

Berdasarkan hasil penelitian, dapat di simpulkan bahwa terdapat hubungan antara tempat pembuangan tinja dengan diare di Daerah Aliran Sungai Tondano dan tidak terdapat hubungan antara tingkat pendidikan, pekerjaan orang tua, usia ibu, sumber air minum dan jenis lantai rumah dengan diare.

\section{SARAN}

1. Bagi institusi kesehatan, perlu ditingkatkan penyuluhan dan sosialiasi kesehatan khususnya tentang hal-hal yang berhubungan dengan kejadian diare. Upaya penyuluhan ini harus dilakukan terus menerus sampai masyarakat betul-betul paham.

2. Perlu ditingkatkan penyuluhan tentang penggunaan MCK di masyarakat yang tinggal di Daerah Aliran Sungai Tondano. 
DAFTAR PUSTAKA

1. Pickering LK, Snyder JD. Gastroenteritis. Nelson Ilmu Kesehatan Anak Vol 2 (Edisi 15). Jakarta: EGC, 1996; p. 889.

2. Parashar UD, Hummelman EG. Bresee JS, Miller MA, and Glass RI. Global illness and deaths caused by rotavirus disease in children. Emerg Infect Dis. 2003;9: 565-72.

3. Amaliah S. Hubungan Sanitasi Lingkungan dan Faktor Budaya dengan Kejadian Diare pada Anak Balita di Desa Toriyo Kecamatan Bendosari Kabupaten Sukoharjo. Semarang: Fakultas Kedokteran Universitas Muhammadiyah; 2010.

4. Adisasmito W. Faktor Risiko Diare pada Bayi dan Balita di Indonesia: Systematic Review Penelitian Akademik Bidang Kesehatan Masyarakat. Makara Kesehatan. 2007;11:1-10.

5. Depkes RI. Keputusan Menteri Kesehatan Republik Indonesia Nomor: 1216/Menkes/SK/XII/2001. Tentang Pedoman Pemberantasan Penyakit Diare. Jakarta: Direktorat Jendral Pemberantasan Penyakit Menular dan Penyehatan Lingkungan Departemen Kesehatan Republik Indonesia.

6. Nugroho SP. Analisis dan Evaluasi Kerusakan Lahan di Daerah Aliran Sungai Tondano. Alami. 2005;10(1).

7. Manampiring AE, Keppel BJ. Studi Populasi Bakteri Resisten Merkuri di
Daerah Aliran Sungai Tondano Kelurahan Ketang Baru Manado.Vol. 11.2011;No 1. Available from: http://ejournal.unsrat.ac.id/index.php/ JIS/article/view/36/32

8. Dinas Kesehatan Provinsi Sulawesi Utara. Profil Kesehatan Provinsi Sulawesi Utara. 2013

9. Irianto J, Soesanto S, Supraptini, Inswiasri, Irianti S, Anwar A. Faktor-faktor yang mempengaruhi kejadian diare pada anak balita ( analisis Lanjut Data SDKI 1994). Buletin penelitian Kesehatan. 1996;24(2 dan 3):77-96. Available from:

http://ejournal.litbang.depkes.go.id/in dex.php/BPK/article/view/429/440.

10.Sander MA. Hubungan Faktor Sosio Budaya dengan Kejadian Diare di Desa Candinegoro kecamatan Wonoayu Sidoarjo. Jurnal Medika. 2005;2(2): 163-93.

11.Departemen Kesehatan RI. Buku Pedoman Pelaksanaan Program P2 Diare. Jakarta: Ditjen PPM dan PPL, 2000.

12.Zubir, Juffrie, Wibowo. Faktor-faktor Resiko Kejadian Diare Akut pada Anak 0-35 bulan di kabupaten Bantul. Sains Kesehatan. 2006;19(3): 319-32.

13. Wibowo T, Soenarto S, Pramono $D$. Faktor-faktor Resiko Kejadian Diare Berdarah pada Balita di Kabupaten Sleman. Berita Kedokteran Masyarakat. 2004; 20(1): 41-8. 